\title{
Pioglitazone inhibits the growth of human leukemia cell lines and primary leukemia cells while sparing normal hematopoietic stem cells
}

\author{
MINORU SAIKI ${ }^{1}$, YOSHIHIRO HATTA ${ }^{1}$, TETSUO YAMAZAKI ${ }^{1}$, TAKEYOSHI ITOH ${ }^{1}$, \\ YUKO ENOMOTO $^{1}$, JIN TAKEUCHI ${ }^{1}$, UMIHIKO SAWADA ${ }^{1}$, SHIN AIZAWA ${ }^{2}$ and TAKASHI HORIE ${ }^{1}$ \\ Departments of ${ }^{1}$ Hematology and Rheumatology, and ${ }^{2}$ Anatomy, \\ Nihon University School of Medicine, 30-1 Oyaguchi, Itabashi-ku, Tokyo 173-8610, Japan
}

Received February 2, 2006; Accepted April 7, 2006

\begin{abstract}
Peroxisome proliferator-activated receptors (PPARs) compose a subfamily of nuclear hormone receptors functioning as transcriptional regulators. Originally, the PPAR $\gamma$ ligand known as thiazolidinedione (TZD) was used for the treatment of diabetic patients. However, recent studies have shown that TZD also has an antitumor effect that inhibits cell growth in several types of human malignant neoplasms, including leukemia cell lines. Since pioglitazone is the only TZD currently available in clinics in Japan and the role of TZD in normal human hematopoietic cells or primary leukemia cells has not been previously reported, we investigated the effect of pioglitazone on human normal hematopoietic progenitor cells, primary leukemia cells, and leukemia cell lines (HL60, K562, U937, HEL, CEM, Jurkat, and NALM1). Pioglitazone inhibited the proliferation of leukemia cells in a dose-dependent manner. The viable cell numbers of HL60, K562, and Jurkat leukemia cell lines were profoundly reduced when the cells were cocultured with pioglitazone. Colony formation in the leukemia cell lines as well as the primary leukemia cells was significantly inhibited to $20-71 \%$ and $1-25 \%$ of that in control cultures by the addition of 100 and $300 \mu \mathrm{M}$ of pioglitazone, respectively. However, the CFU-E and CFU-GM colonies of cells obtained from healthy volunteers were not altered in the presence of $100 \mu \mathrm{M}$ of pioglitazone. Pioglitazone $(300 \mu \mathrm{M})$ induced slight decrease of CFU-E and CFU-GM. BFU-E was more sensitive to pioglitazone than CFU-E and CFU-GM. Pioglitazoneinduced growth inhibition in HL60 cells was associated with cell cycle arrest at the G1 phase, as has been reported for another TZD, troglitazone. Similar levels of PPAR $\gamma$ protein were observed in both leukemia and normal bone marrow
\end{abstract}

Correspondence to: Dr Yoshihiro Hatta, Department of Hematology and Rheumatology, Nihon University School of Medicine, 30-1 Oyaguchi, Itabashi-ku, Tokyo 173-8610, Japan

E-mail: yhatta@med.nihon-u.ac.jp

Key words: pioglitazone, PPAR $\gamma$, leukemia, hematopoietic stem cell cells by Western blotting, suggesting that the expression of PPAR $\gamma$ protein was not associated with the inhibitory potency of pioglitazone. In conclusion, our results suggest that pioglitazone may offer a new therapeutic approach to aid in the treatment of leukemia.

\section{Introduction}

Many leukemia patients achieve complete remission with current treatment protocols, while some of the patients eventually relapse and have shortened survival periods. Therefore, the development of effective and novel therapies for patients with refractory or relapsed leukemia is needed to improve patient outcome.

Peroxisome proliferator-activated receptors (PPARs) belong to a subfamily of nuclear hormone receptors that regulate the transcription of target genes through activation by PPAR ligands. To date, three subtypes of PPARs have been identified; termed $\alpha, \beta$, and $\gamma$, each subtype is encoded by a separate gene and has a distinct tissue distribution pattern (1). PPAR $\gamma$ was initially noted to be highly expressed in adipose tissue and to have a regulatory function in adipocyte differentiation, insulin sensitization and lipid metabolism $(2,3)$. However, a recent study demonstrated that PPAR $\gamma$ is expressed in a variety of cancer cells and has crucial roles in the suppression of cell growth (4). Thiazolidinedione (TZD) is a high-affinity ligand for PPAR $\gamma$ (5). Troglitazone and pioglitazone are two TZD derivatives that share a common thiazolidine-2-4-dione structure, which is responsible for the majority of the pharmacological actions of these compounds. Although these TZDs are able to normalize elevated plasma glucose levels in obese, diabetic rodents (6), data suggest that TZDs also have antitumor effects against liposarcomas $(7,8)$, glioblastomas (9), colon cancers $(10,11)$, pancreatic cancers (12-15), breast cancers $(16,17)$, prostate cancers $(18,19)$, esophageal cancers $(20,21)$, gastric cancers $(22,23)$, lung cancers $(24,25)$, oral cancers (26), salivary gland cancers (27), liver cancers (28) and thyroid cancers (29).

Fujimura et al reported the cytotoxic effect of troglitazone on leukemia cell lines (30), and Asou et al reported that troglitazone was a moderately potent inhibitor of the clonogenic growth of acute myeloid leukemia cell lines when 
combined with a retinoid (31). However, troglitazone has been withdrawn from clinical use because it causes liver toxicity. Ciglitazone, another TZD, was never used clinically because of several adverse-effects. Therefore, pioglitazone is the only TZD currently in clinical use in Japan for the treatment of type II diabetes without major side-effects. These observations led us to perform a preclinical study of pioglitazone as a novel therapeutic agent for leukemia. Zang et al reported that pioglitazone induced growth inhibition and apoptosis of human B lymphocytic leukemia cell lines (32). However, the effect of pioglitazone upon human myeloid leukemia cell lines, primary leukemia cells, and normal hematopoietic stem cells is unknown. In the present study, we investigated the effect of pioglitazone on various leukemia cell lines and primary leukemia cells as well as on normal hematopoietic stem cells in vitro.

\section{Materials and methods}

Reagents. RPMI-1640 medium, fetal calf serum (FCS), and phytohemagglutinin (PHA) were obtained from Sigma Aldrich Co. (St. Louis, MO, USA); anti-human PPAR $\gamma$ antibody (sc-7196, rabbit IgG) was obtained from Santa Cruz Biotechnology Inc. (Santa Cruz, CA, USA). Pioglitazone was kindly provided by Takeda Chemical Industries (Tokyo, Japan) and was dissolved with $100 \%$ dimethyl sulfoxide (DMSO) to a concentration of $400 \mathrm{mM}$, then stored at $4{ }^{\circ} \mathrm{C}$ in the dark until use. The stock solution was further diluted with RPMI-1640 medium before use. Control cultures received the same amount of DMSO, which was always $<0.1 \%(\mathrm{v} / \mathrm{v})$ of the culture medium. This concentration of DMSO had no effect on the proliferation of these cells. All other reagents were purchased from Nacalai Tesque Co. (Kyoto, Japan).

Cells. HL60 (myelocytic leukemia), K562 (erythroid blast crisis of chronic myelocytic leukemia), U937 (monocytic leukemia), HEL (erythroleukemia), CEM (T-lymphoblastic leukemia), Jurkat (T-lymphoblastic leukemia), and NALM1 (B-lymphoblastic leukemia) cells were grown in RPMI-1640 medium with $10 \%$ FCS supplemented with $100 \mathrm{U} / \mathrm{ml}$ penicillin and $100 \mu \mathrm{g} / \mathrm{ml}$ streptomycin. These cells were incubated at $37^{\circ} \mathrm{C}$ in a humidified $5 \% \mathrm{CO}_{2}$ incubator. Bone marrow cells were obtained by needle aspiration from healthy volunteers, and leukemia cells were obtained from heparinized peripheral blood samples from leukemia patients. Informed consent was obtained prior to blood sampling.

Liquid cultures. Three leukemia cell lines, HL60, K562, and Jurkat, were grown in RPMI-1640 medium supplemented with $10 \% \mathrm{FCS}$; at a concentration of $1 \times 10^{4} / \mathrm{ml}$, the cultures were incubated with various concentrations of pioglitazone at $37^{\circ} \mathrm{C}$ in a humidified atmosphere of $5 \% \mathrm{CO}_{2}$ in air. After 3 , 5 , and 7 days of incubation, the number of viable cells was counted using the trypan-blue dye exclusion procedure. All experiments were repeated at least three times.

Colony formation assay. Five hundred cells of HL60, HEL and NALM1 and one thousand cells of U937, K562 and CEM were incubated in $35-\mathrm{mm}$ dishes containing $1 \mathrm{ml}$ of
RPMI-1640 medium supplemented with 10\% FCS and 1.7\% methylcellulose semi-solid culture in the presence of 100 or $300 \mu \mathrm{M}$ of pioglitazone, respectively. Triplicate cultures were incubated at $37^{\circ} \mathrm{C}$ in a humidified atmosphere of $5 \%$ $\mathrm{CO}_{2}$ in air. Microscopic colonies were counted seven days later. All experiments were performed at least three times.

Leukemia blast colony assay. Heparinized peripheral blood was obtained from four patients with acute myeloid leukemia (AML). The morphology of the leukemia cells was classified according to the criteria of the French-American-British (FAB) committee. The subtypes and the number of cases were as follows: M3 $(n=1), M 4(n=1)$, and leukemic transformation from myelodysplastic syndrome (MDS; $\mathrm{n}=2$ ). Peripheral blood mononuclear cells (PBMNCs) were separated by centrifugation through a Ficoll-Conray (meglumine iotalamate; Mallinckrodt, St. Louis, MO, USA) density gradient (density, $1.077 \mathrm{~g} / \mathrm{dl}$ ). Subsequently, a specific additional T-lymphocyte depletion of the PBMNC fraction was performed by immunomagnetic separation using anti-CD3 Dynabeads (Dynal, Hamburg, Germany). PBMNCs were incubated in a culture flask with the beads at a target cell ratio of 20:1. Then, the flask was placed twice onto a 'Magnetic Particle Concentrator (MPC)'. The $\mathrm{CD}^{+} \mathrm{T}$-lymphocytes rosetted by the beads were attached to the wall of the flask by the MPC, while the CD3-negative supernatant was collected for the assay. A total of $5 \times 10^{4}-10^{5}$ blast cells were plated in $35-\mathrm{mm}$ dishes containing $1 \mathrm{ml}$ of RPMI-1640 medium supplemented with $10 \%$ FCS, $1.7 \%$ methylcellulose, and either 100 or $300 \mu \mathrm{M}$ of pioglitazone at the final concentration. As a colony stimulating factor (CSF), 10\% PHA-stimulated leukocyte-conditioned medium (PHA-LCM) obtained by culturing normal leukocytes with PHA in a serum-free culture for seven days was used. Triplicate cultures were incubated at $37^{\circ} \mathrm{C}$ in a humidified atmosphere of $5 \% \mathrm{CO}_{2}$ in air. Microscopic colonies were counted seven days later. The mean \pm SD was calculated for samples from four AML patients.

Assay for CFU-GM, CFU-E, and BFU-E. To examine whether pioglitazone affects the proliferation of normal hematopoietic progenitor cells, CFU-GM, CFU-E, and BFU-E were assayed with either 100 or $300 \mu \mathrm{M}$ of pioglitazone using a MethoCult GF H4434V (Stemcell Technologies, Vancouver, Canada) according to the manufacturer's instructions. Briefly, $10^{5}$ bone marrow mononuclear cells (BMMNCs) were plated in 35-mm plates with $1.5 \mathrm{ml}$ of MethoCult GF H4434V methylcellulose medium and an appropriate concentration of pioglitazone per plate; experiments were performed in triplicate. The plates were cultured for 12-14 days in a humidified incubator at $37^{\circ} \mathrm{C}$ and $5 \% \mathrm{CO}_{2}$. The colonies (>50 cells) were counted using a dissecting microscope.

Western blotting. The cells were collected and lysed in $0.1 \mathrm{ml}$ of solubilizing buffer containing $0.5 \%$ NP-40, $10 \mathrm{mM}$ Tris$\mathrm{HCl}, 150 \mathrm{mM} \mathrm{NaCl}, 1 \mathrm{mM}$ PMSF (Calbiochem, La Jolla, CA, USA), $0.111 \mathrm{U} / \mathrm{ml}$ aprotinin (Sigma) and $0.02 \% \mathrm{NaN}_{3}$ in isopropanol. The cell lysates were mixed with sample buffer (0.0625 M Tris-base, 10\% glycerol, $100 \mathrm{mM}$ DTT and $2.3 \%$ SDS), and then heated in a boiling water bath for $5 \mathrm{~min}$ to fully denature the proteins prior to electrophoresis. Equal 
[HL60]

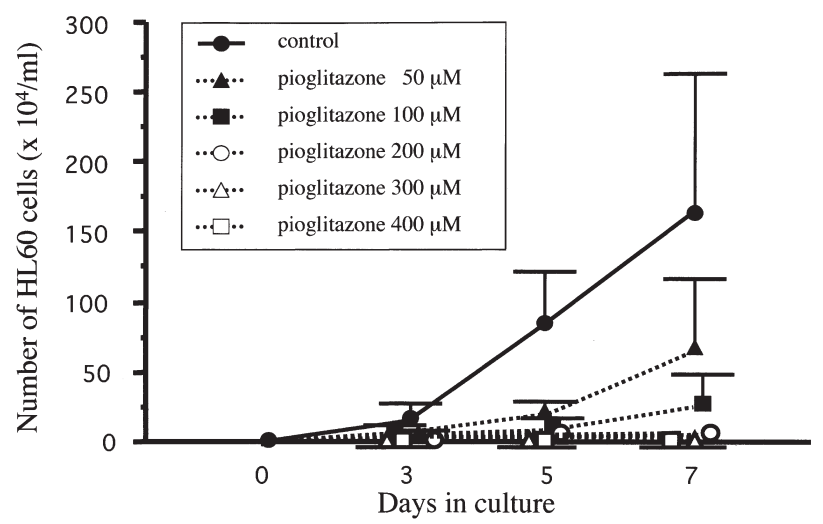

Figure 1. Changes in the number of HL60 cells cultured in the presence of pioglitazone. HL60 cells $\left(1 \times 10^{4} / \mathrm{ml}\right)$ were cultured with various concentrations of pioglitazone, and the number of viable cells was counted using the trypan-blue dye exclusion method. HL60 cells were collected from different dishes at each point, and the results expressed as the mean \pm SD were obtained from triplicate experiments.

amounts of protein $(10 \mathrm{mg} / \mathrm{lane})$ were separated on a $10 \%$ SDS gel and transferred to a polyvinylidene difluoride membrane (Millipore, Bedford, MA, USA) by electroelution with a constant current of $200 \mathrm{~mA}$ for $90 \mathrm{~min}$ at room temperature. After blocking with $0.05 \%$ Tween-20 in PBS (T-PBS) containing 10\% FCS and 5\% skim-milk overnight, the membrane was incubated with anti-human PPAR $\gamma$ antibody $(1 \mu \mathrm{g} / \mathrm{ml})$ for $1 \mathrm{~h}$ at room temperature. The membrane was then washed with T-PBS three times and incubated with horseradish peroxidase-conjugated secondary antibodies (Lake Placid, $\mathrm{NY}$, and Amersham, UK) for $1 \mathrm{~h}$ at room temperature. After washing six times with T-PBS, the membrane was treated with Enhanced Chemiluminescence (ECL) solution (Amersham, RPN 2106) for $1 \mathrm{~min}$ according to the manufacturer's instructions, and exposed to Fuji medical X-ray film (AIF new RX) for $1 \mathrm{~min}$.

Cell cycle analysis. After a quantity of $2 \times 10^{5}$, HL60 cells were exposed to $100 \mu \mathrm{M}$ pioglitazone or control medium for $48 \mathrm{~h}$ in liquid culture, the total cells were collected and washed with PBS. The cells were resuspended in $500 \mu \mathrm{l}$ of a hypotonic solution containing $50 \mu \mathrm{g} / \mathrm{ml}$ propidium iodide (PI) in $0.1 \%$ sodium citrate plus $0.2 \%$ Triton $\mathrm{X}-100$. After incubation for $4 \mathrm{~h}$ at $4^{\circ} \mathrm{C}$ in the dark, nuclei were acquired using a FACScan flow cytometer (Becton-Dickinson, San Jose, CA, USA). Data for 10,000 events were saved as listmode files and analyzed with CellFIT software (BectonDickinson). Doublets were excluded on an FL2 area/FL2 wide (FL2-A/FL2-W) dot plot. G0/G1, S, and G2/M phases of the cell cycle were analyzed using an FL2-A histogram.

Statistical analysis. The data obtained in these experiments were evaluated using a Student's t-test. A p $<0.05$ was considered statistically significant.

\section{Results}

Effect of pioglitazone on the cell growth of human leukemia cells. Cloned leukemia cells, HL60, K562, and Jurkat, were

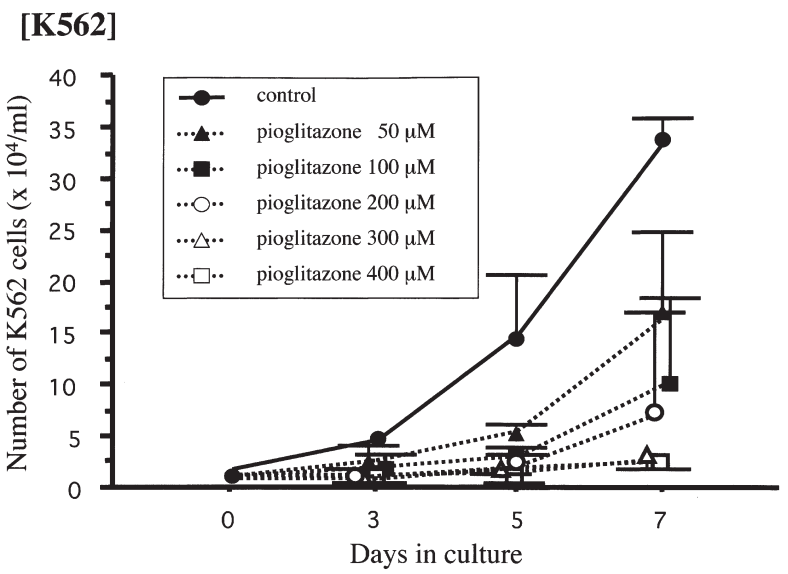

Figure 2. Changes in the number of Jurkat cells cultured in the presence of pioglitazone. Jurkat cells were incubated and processed as in Fig. 1.

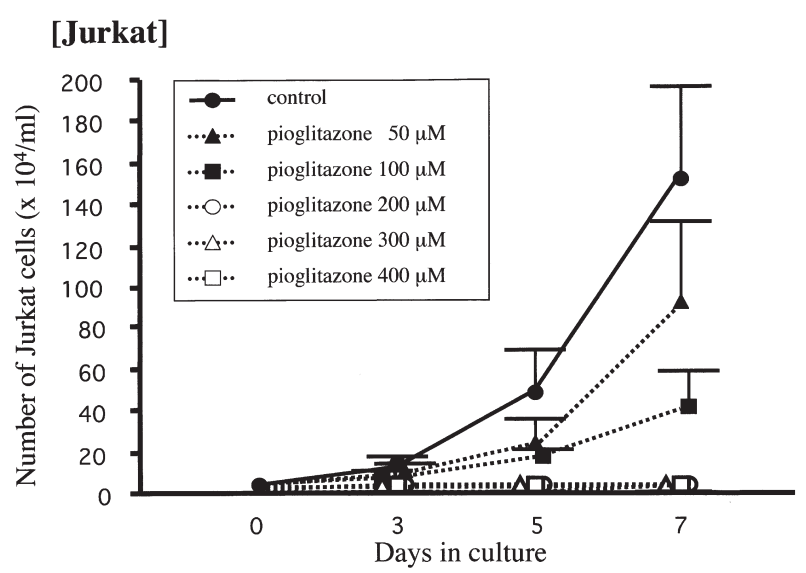

Figure 3. Changes in the number of K562 cells cultured in the presence of pioglitazone. K562 cellls were incubated and processed as in Fig. 1.

cultured in the presence of various concentrations of pioglitazone and the number of variable cells was counted on days 3, 5, and 7. The growth of HL60, K562, and Jurkat cells was significantly inhibited in a dose-dependent manner. Coculture with $200 \mu \mathrm{M}$ of pioglitazone for seven days completely inhibited the growth of HL60 and Jurkat cells (Figs. 1 and 2). Pioglitazone $(300 \mu \mathrm{M})$ induced the complete inhibition of the proliferation in K562 cells (Fig. 3). HL60, K562, U937, HEL, CEM, and NALM1 were then incubated in a semi-solid culture in the presence of either 100 or $300 \mu \mathrm{M}$ of pioglitazone. In semi-solid cultures, pioglitazone also inhibited the in vitro growth of all human leukemia cell lines tested in a dose-dependent manner. In the presence of $100 \mu \mathrm{M}$ of pioglitazone, colony formation in all the cell lines significantly decreased to $20.8-71.8 \%$ of that seen in control cultures $(\mathrm{p}<0.01)$. In addition, $300 \mu \mathrm{M}$ of pioglitazone strongly inhibited the growth of clonogenic cells to $1.0-25.2 \%$ of that seen in control cultures $(\mathrm{p}<0.01)$ (Fig. 4). When primary leukemia cells from AML patients were incubated using a similar method, colony formation was significantly inhibited. The number of leukemia cell colonies in the presence of 100 or $300 \mu \mathrm{M}$ of pioglitazone was reduced to $54.9 \pm 14.8 \%$ and $23.1 \pm 11.6 \%$ of that seen in control cultures, respectively $(\mathrm{p}<0.01)$ (Fig. 5). 

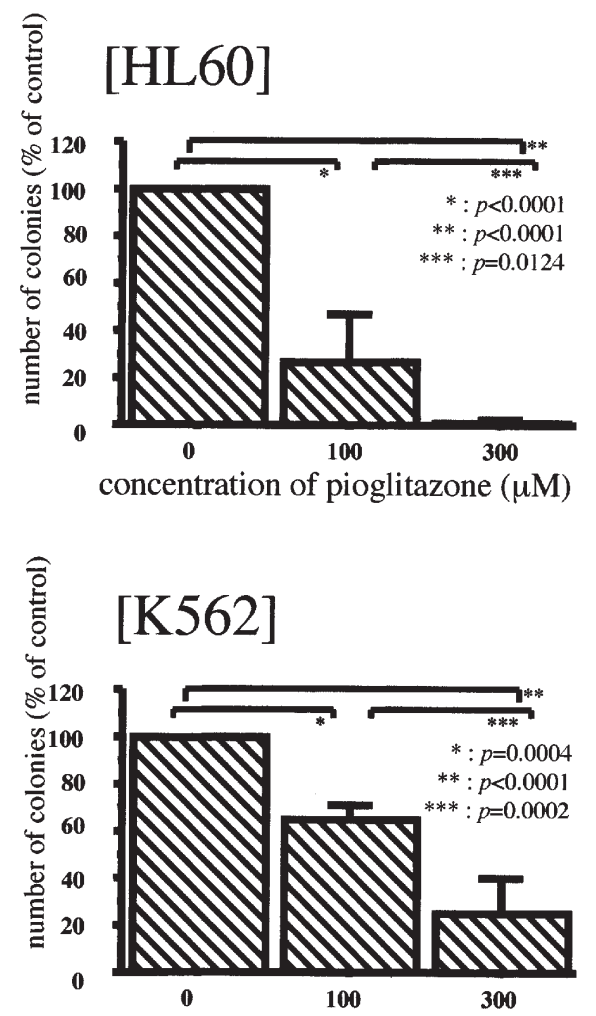

concentration of pioglitazone $(\mu \mathrm{M})$
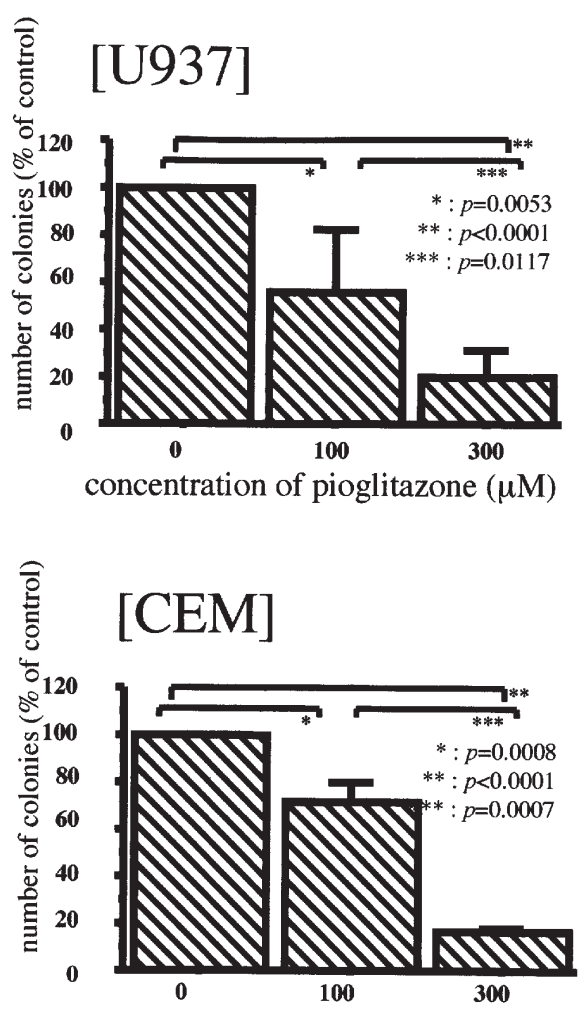

concentration of pioglitazone $(\mu \mathrm{M})$
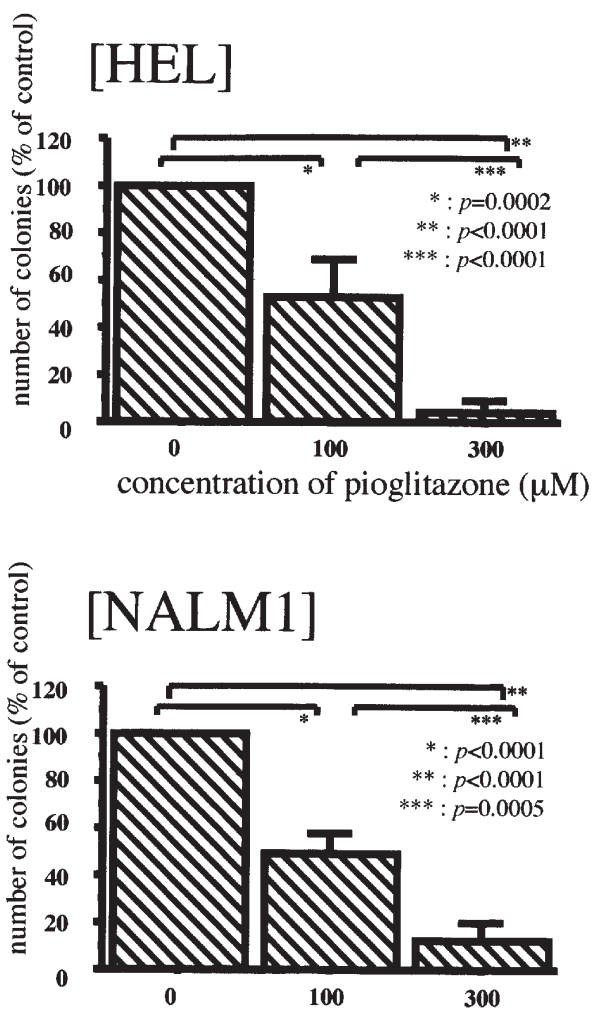

concentration of pioglitazone $(\mu \mathrm{M})$

Figure 4. Effect of pioglitazone on colony formation in human leukemia cell lines. A total of 500-1000 cells were incubated in semi-solid culture conditions in the presence of 100 or $300 \mu \mathrm{M}$ of pioglitazone, respectively. The results were expressed as a percentage of the control. Each bar represents the mean $\pm \mathrm{SD}$ obtained from triplicate experiments. The administration of pioglitazone $(100$ and $300 \mu \mathrm{M})$ significantly decreased colony formation (p<0.01), compared with that in control cultures.

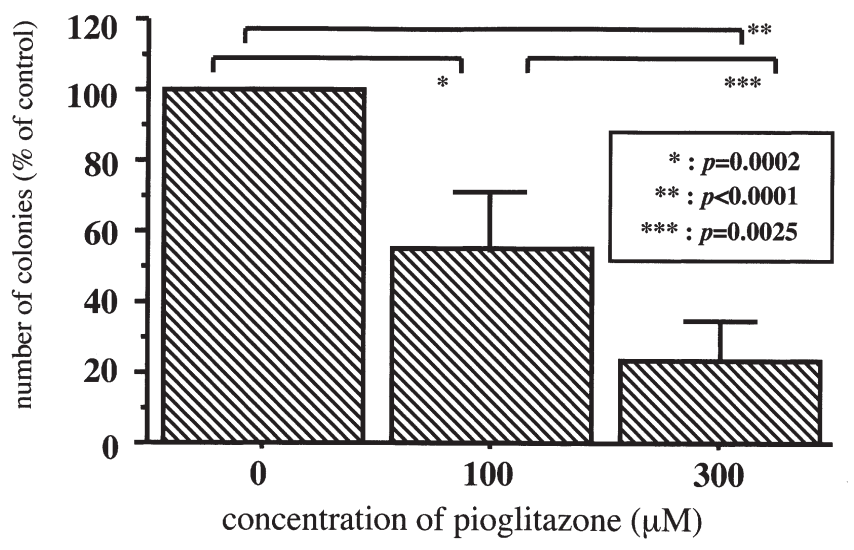

Figure 5. Effect of pioglitazone on colony formation in human primary leukemia cells. A total of $5 \times 10^{4}-10^{5}$ blast cells were incubated in semi-solid culture conditions with PHA-LCM in the presence of 100 or $300 \mu \mathrm{M}$ of pioglitazone. The results were expressed as a percentage of the control. Each bar represents the mean \pm SD obtained from triplicate experiments. The administration of pioglitazone (100 and $300 \mu \mathrm{M})$ significantly decreased colony formation, compared with that in control cultures $(\mathrm{p}<0.01)$.

Effect of pioglitazone on CFU-GM, CFU-E, and BFU-E colony formation. Fig. 6 shows the growth of BFU-E, CFU-E, and CFU-GM incubated with pioglitazone. In the control cultures, the absolute number of CFU-GM, CFU-E, and BFU-E colonies was $118 \pm 61,35 \pm 13$, and $46 \pm 16$ per $10^{5}$ cells, respectively. Both CFU-GM and CFU-E showed no significant decrease in colony formation when cultured in the presence of $100 \mu \mathrm{M}$ of pioglitazone. In the presence of $100 \mu \mathrm{M}$ of pioglitazone, $86.9 \pm 21.8 \%$ of CFU-E and $76.6 \pm 14.7 \%$ of CFU-GM colonies survived. Pioglitazone (300 $\mu \mathrm{M})$ slightly decreased CFU-E and CFU-GM colonies to $69.8 \pm 30.2 \%$ $(\mathrm{p}<0.05)$ and $81.5 \pm 18.2 \%(\mathrm{p}<0.01)$ of control, respectively. BFU-E was more sensitive to pioglitazone than CFU-E and CFU-GM. Overall, 60.7 $\pm 22.4 \%(\mathrm{p}<0.01)$ and $33.3 \pm 18.4 \%$ $(\mathrm{p}<0.01)$ of BFU-E colonies survived in the presence of 100 and $300 \mu \mathrm{M}$ of pioglitazone, respectively.

Assay for the expression of PPAR protein. The presence of an $\sim 48-\mathrm{kDa}$ band, conforming to the expected band for the PPAR $\gamma$ protein, was observed in all six leukemia cell lines, in a monitor of primary leukemia cells, and in human normal bone marrow mononuclear cells. The amount of PPAR $\gamma$ protein was similar in all cells (Fig. 7).

Cell cycle analysis. Based on the growth inhibitory effect of pioglitazone observed in HL60 cells, we further examined the effect of pioglitazone on cell cycle progression. After $48 \mathrm{~h}$ of culture in the presence of $100 \mu \mathrm{M}$ of pioglitazone, the percentages of $\mathrm{G} 1, \mathrm{~S}$, and $\mathrm{G} 2 / \mathrm{M}$ phase cells were $52.9 \pm 10.5 \%$, $40.5 \pm 10.5 \%$, and $6.7 \pm 2.1 \%$, respectively, whereas the distribution in control cultures was $42.5 \pm 2.8 \%, 45.3 \pm 4.7 \%$, and $12.3 \pm 3.9 \%$. The decrease in $\mathrm{G} 2 / \mathrm{M}$ phase cells and the increase in $\mathrm{G} 1$ phase cells in the pioglitazone-treated group, compared with that in the control group, suggested that pioglitazone 

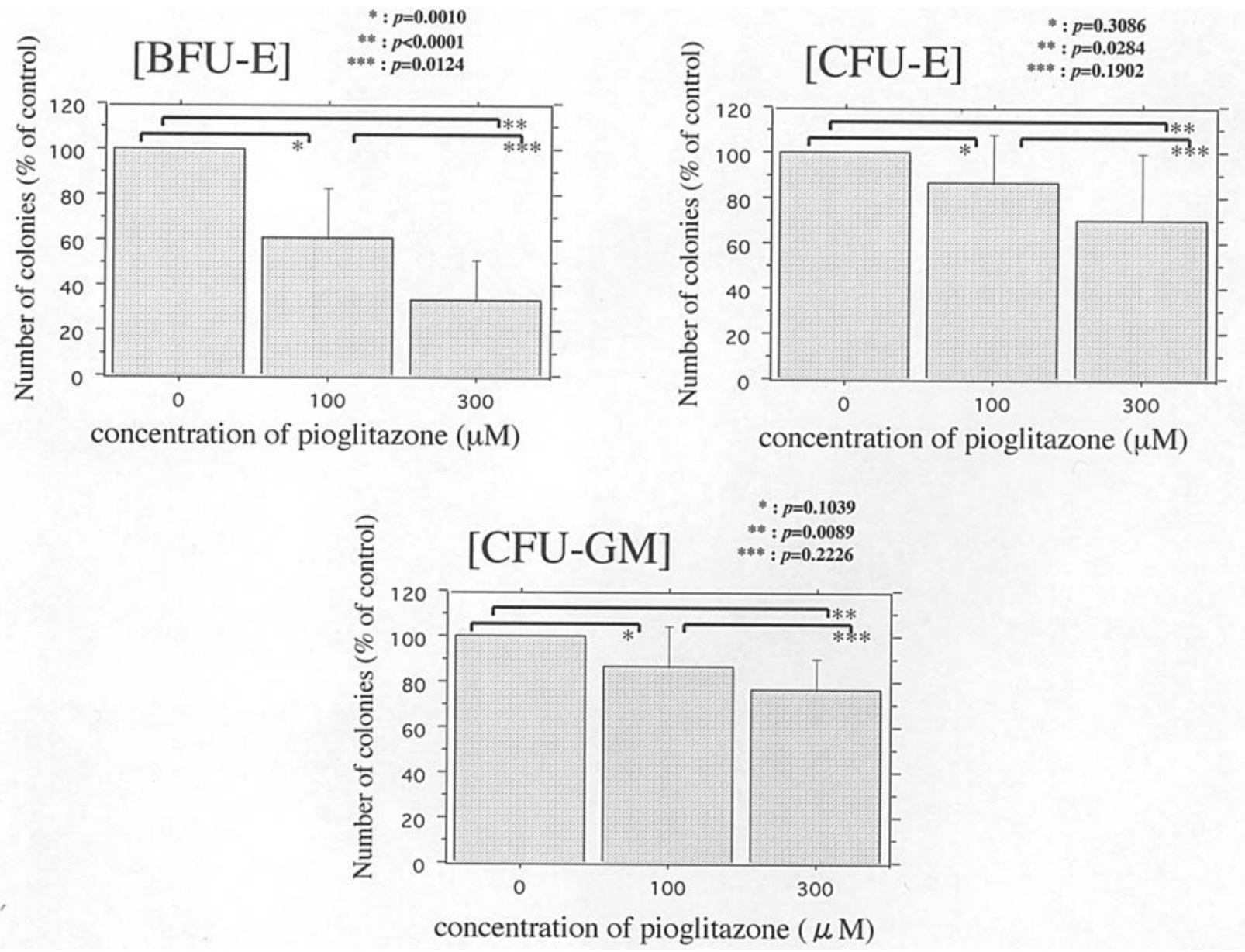

Figure 6. Effect of pioglitazone on CFU-GM, CFU-E, and BFU-E colony formation in normal bone marrow cells. CFU-GM, CFU-E, and BFU-E were assayed in the presence of 100 or $300 \mu \mathrm{M}$ of pioglitazone. The results were expressed as a percentage of the control. Each bar represents the mean \pm SD from triplicate experiments.

\section{[K562] [HL60] [U937] [CEM] [HEL] [NALM1]}

$\operatorname{PPAR} \gamma$

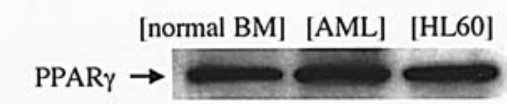

Figure 7. Expression of the PPAR $\gamma$ protein. Upper lane 1, K562 (chronic myelocytic leukemia, erythroid blast crisis); upper lane 2, HL60 (myelocytic leukemia); upper lane 3, U937 (monocytic leukemia); upper lane 4, CEM (T-lymphoblastic leukemia); upper lane 5, HEL (erythroleukemia); upper lane 6, NALM1 (B-lymphoblastic leukemia); lower lane 1, bone marrow mononuclear cells from healthy donor; lower lane 2, bone marrow blast cells from a patient with acute myelocytic leukemia; lower lane 3, HL60. Arrows indicate the $\sim 48-\mathrm{kDa}$ band, agreeing with the expected band for PPAR $\gamma$.

induced cell cycle arrest at the G1 phase in HL60 cells. A representative cell cycle analysis is shown in Fig. 8.

\section{Discussion}

TZD has been used as an antidiabetic agent to improve hyperglycemia and hyperlipidemia in patients with type II diabetes mellitus. However, recent studies have shown that
TZD not only induces adipocyte differentiation and increase insulin sensitivity, but also exerts growth inhibitory effects on several carcinoma cell lines, both in vitro and in vivo. Three TZDs have been widely studied: troglitazone, ciglitazone, and pioglitazone. The clinical use of troglitazone has been discontinued because it causes fatal hepatic injury. Ciglitazone was never used clinically because of several adverse-effects. Therefore, pioglitazone is the only clinically available TZD in Japan. Pioglitazone (AD-4833)- $\mathrm{HCl}$ is freely soluble in DMSO, soluble in methanol, slightly soluble in dehydrated ethanol, very slightly soluble in water, and practically insoluble in ether. In this study, we investigated the cytotoxic effect of pioglitazone on the growth of leukemia and normal hematopoietic progenitor cells. As far as we know, this is the first report to describe the effect of pioglitazone on normal hematopoietic progenitor cells and primary leukemia cells. Pioglitazone inhibited the growth of all leukemia cell lines in a dose-dependent manner. In the presence of 100 or $300 \mu \mathrm{M}$ of pioglitazone, the proliferation of all the leukemia cell lines that were tested and of the primary leukemia cells was significantly inhibited, while the antiproliferative effect was negligible in normal CFU-E and CFU-GM cells cultured under the same conditions. These findings suggest that pioglitazone may be a useful chemotherapeutic agent for the treatment of leukemia. 

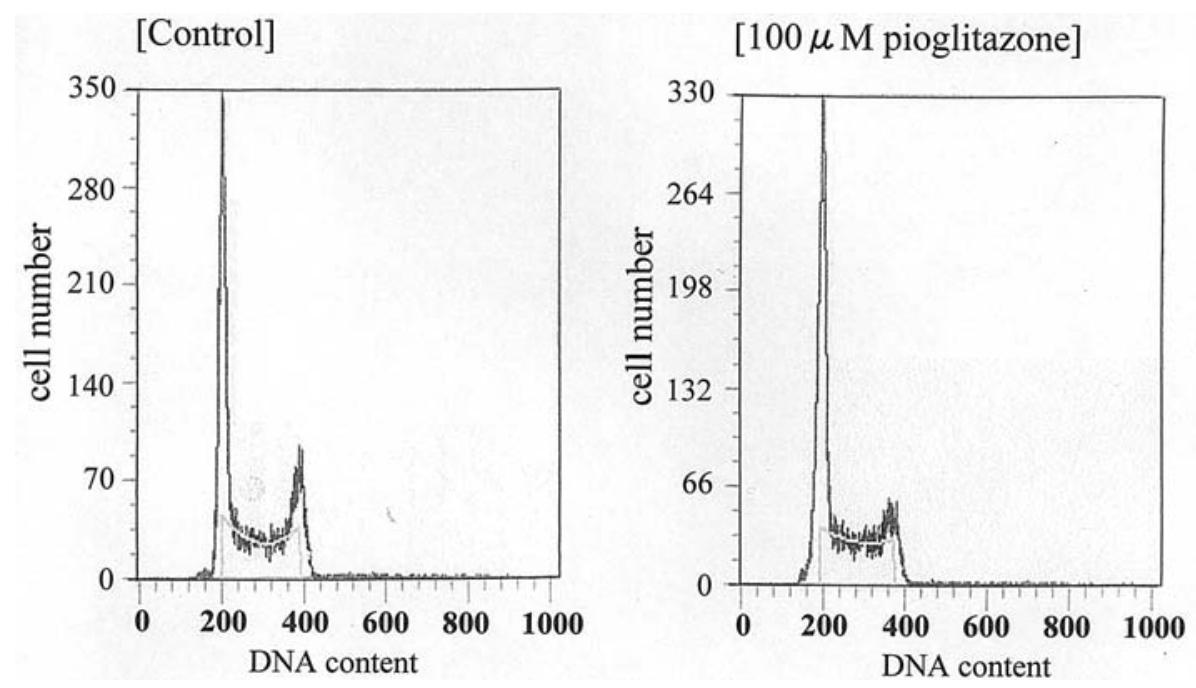

Figure 8. Representative cell cycle analysis. HL60 cells were cultured with control medium or medium containing $100 \mu \mathrm{M}$ of pioglitazone for $48 \mathrm{~h}$. An increase in the G1 peak and a decrease in the G2/M peak were identified in the pioglitazone-treated cells.

The treatment of HL60 cells with pioglitazone resulted in cell cycle arrest, as was reported for troglitazone (30). Many previous studies have demonstrated that the activation of PPAR $\gamma$ induces growth inhibition associated with G1 arrest in PPAR $\gamma$-expressing neoplasms (10-13,15,16,18,20-23,28,31-33). Alterations in the key regulators of the G1/S transition, such as cyclins, cyclin-dependent kinases (CDKs) and CDK inhibitors (p21/WAF1 and p27/KIP1), may be responsible for the PPAR $\gamma$ ligand-induced cell cycle arrest in a variety of tumor cells. The down-regulation of cyclin D1, CDK2, and CDK4 in human lymphoblastic leukemia cells (32) and other cancer cells (24,34-36) was identified when these cells were exposed to TZDs. In addition, troglitazone has been reported to induce p21/WAF1 in myeloid leukemia cell lines (37) and p27/KIP1 in pancreatic carcinoma cells (12). However, these observations are controversial (4). Further studies are needed to clarify the mechanism by which pioglitazone inhibits cell growth in leukemia cells.

We also studied the expression of PPAR $\gamma$ protein. All cell lines, blasts from AML patients and normal bone marrow cells expressed a similar amount of PPAR $\gamma$ protein, as demonstrated by Western blotting, suggesting that the effect of pioglitazone seems to be independent of the PPAR $\gamma$ protein. Previously, a number of publications suggested that the effects of TZDs were independent of PPARs $(31,38,39)$. First, TZDs inhibited the growth of PPAR $\gamma$-/- embryonic stem cells in mice (40). Furthermore, the inhibitory effects of troglitazone on cellular proliferation were also observed in keratinocytes not expressing PPAR $\gamma$ (36). Secondly, another PPAR $\gamma$ ligand, GW7845 (41), has no anti-proliferative effects on leukemia cells (32). Thirdly, several PPAR $\gamma$ antagonists could not reverse the cytotoxicity of pioglitazone (32). Finally, to exert an antiproliferative activity, TZDs must be used at much higher concentrations than those required to activate PPARs (32). Further studies are needed to clarify the mechanism by which pioglitazone inhibits cell growth in leukemia cells.

In conclusion, we have presented evidence that the PPAR $\gamma$ protein is expressed in leukemia as well as normal bone marrow cells and that pioglitazone inhibits the growth of leukemia cells in vitro. Further, pioglitazone is more cytotoxic to leukemia cells than to normal hematopoietic progenitor cells, suggesting that pioglitazone should be considered as a novel therapeutic agent for the management of leukemia patients. Future studies should clarify the mechanisms of pioglitazone's antileukemia effect.

\section{Acknowledgments}

We are grateful to Takeda Chemical Industries (Tokyo, Japan) for providing the pioglitazone as a gift.

\section{References}

1. Valentiner U, Carlsson M, Erttmann R, Hildebrandt $\mathrm{H}$ and Schumacher U: Ligands for the peroxisome proliferator-activated receptor-gamma have inhibitory effects on growth of human neuroblastoma cells in vitro. Toxicology 213: 157-168, 2005.

2. Chawla A, Schwarz EJ, Dimaculangan DD and Lazar MA: Peroxisome proliferator-activated receptor (PPAR) gamma: adipose-predominant expression and induction early in adipocyte differentiation. Endocrinology 135: 798-800, 1994.

3. Spiegelman BM: PPAR- $\gamma$ : adipogenic regulator and thiazolidinedione receptor. Diabetes 47: 507-514, 1998.

4. Hupfeld CJ and Weiss RH: TZDs inhibit vascular smooth muscle cell growth independently of the cyclin kinase inhibitors p21 and p27. Am J Physiol Endocrinol Metab 281: E207-E216, 2001.

5. Lehmann JM, Moore LB, Smith-Oliver TA, Wilkinson WO, Willson TM and Kliewer SA: An antidiabetic thiazolidinedione is a high affinity ligand for peroxisome proliferator-activated receptor gamma (PPAR gamma). J Biol Chem 270: 12953-12956, 1995.

6. Chang AY, Wyse BM, Gilchrist BJ, Peterson T and Diani AR: Ciglitazone, a new hypoglycemic agent. I. Studies in ob/ob and $\mathrm{db} / \mathrm{db}$ mice, diabetic Chinese hamsters, and normal and streptozotocin-diabetic rats. Diabetes 32: 830-838, 1983.

7. Tontonoz P, Singer S, Forman BM, Sarraf P, Fletcher JA, Fletcher CD, Brun RP, Mueller E, Altiok S, Oppenheim H, Evans RM and Spiegelman BM: Terminal differentiation of human liposarcoma cells induced by ligands for peroxisome proliferators-activated receptor gamma and the retinoid $\mathrm{X}$ receptor. Proc Natl Acad Sci USA 94: 237-241, 1997.

8. Demetri GD, Fletcher CD, Mueller E, Sarraf P, Naujoks R, Campbell N, Spiegelman BM and Singer S: Induction of solid tumor differentiation by the peroxisome proliferator-activated receptor-gamma ligand troglitazone in patients with liposarcoma. Proc Natl Acad Sci USA 96: 3951-3956, 1999. 
9. Morosetti R, Servidei T, Mirabella M, Rutella S, Mangiola A, Maira G, Mastrangelo R and Koeffler HP: The PPARgamma ligands PGJ2 and rosiglitazone show a differential ability to inhibit proliferation and to induce apoptosis and differentiation of human glioblastoma cell lines. Int J Oncol 25: 493-502, 2004.

10. Brockman J, Gupta R and Dubois R: Activation of PPAR $\gamma$ leads to inhibition of anchorage-independent growth of human colorectal cancer cells. Gastroenterology 115: 1049-1055, 1998.

11. Yoshizumi T, Ohta T, Ninomiya I, Terada I, Fushida S, Fujimura T, Nishimura G, Shimizu K, Yi S and Miwa K: Thiazolidinedione, a peroxisome proliferator-activated receptorgamma ligand, inhibits growth and metastasis of HT-29 human colon cancer cells through differentiation-promoting effects. Int J Oncol 25: 631-639, 2004.

12. Motomura W, Okamura T, Takahashi N, Obara T and Kohgo Y: Activation of peroxisome proliferator-activated receptor gamma by troglitazone inhibits cell growth through the increase of p27KiP1 in human pancreatic carcinoma cells. Cancer Res 60: 5558-5564, 2000.

13. Elnemr A, Ohta T, Iwata K, Ninomiya I, Fushida S, Nishimura G, Kitagawa H, Kayahara M, Yamamoto M, Terada T and Miwa K: PPAR $\gamma$ ligand (thiazolidinedione) induces growth arrest and differentiation markers of human pancreatic cancer cells. Int $\mathbf{J}$ Oncol 17: 1157-1164, 2000.

14. Ohta T, Elnemr A, Yamamoto M, Ninomiya I, Fushida S, Nishimura G, Fujimura T, Kitagawa H, Kayahara M, Shimizu K, Yi S and Miwa K: Thiazolidinedione, a peroxisome proliferatorsactivated receptor-gamma ligand, modulates the E-cadherin/ beta-catenin system in a human pancreatic cancer cell line, BxPC-3. Int J Oncol 21: 37-42, 2002.

15. Tsujie M, Nakamori S, Okami J, Takahashi Y, Hayashi N, Nagano H, Dono K, Umeshita K, Sakon M and Monden M: Growth inhibition of pancreatic cancer cells through activation of peroxisome proliferator-activated receptor gamma/retinoid X receptor alpha pathway. Int J Oncol 23: 325-331, 2003.

16. Elstner E, Muller C, Koshizuka K, Williamson EA, Park D, Asou H, Shintaku P, Said JW, Heber D and Koeffler HP: Ligands for peroxisome proliferator-activated receptor gamma and retinoic acid receptor inhibit growth and induce apoptosis of human breast cancer cells in vitro and in BNX mice. Proc Natl Acad Sci USA 95: 8806-8811, 1998.

17. Yee LD, Sabourin CL, Liu L, Li HM, Smith PJ, Seewaldt V and Kniss DA: Peroxisome proliferator-activated receptor gamma activation in human breast cancer. Int J Oncol 15: 967-973, 1999.

18. Kubota T, Koshizuka K, Williamson EA, Asou H, Said JW, Holden S, Miyoshi I and Koeffler HP: Ligand for peroxisome proliferator-activated receptor gamma (troglitazone) has potent antitumor effect against human prostate cancer both in vitro and in vivo. Cancer Res 58: 3344-3352, 1998.

19. Shiau CW, Yang CC, Kulp SK, Chen KF, Chen CS, Huang JW and Chen CS: Thiazolidenediones mediate apoptosis in prostate cancer cells in part through inhibition of Bcl-xL/Bcl-2 functions independently of PPARgamma. Cancer Res 65: 1561-1569, 2005.

20. Takashima T, Fujiwara Y, Higuchi K, Arakawa T, Yano Y, Hasuma T and Otani S: PPAR-gamma ligands inhibit growth of human esophageal adenocarcinoma cells through induction of apoptosis, cell cycle arrest and reduction of ornithine decarboxylase activity. Int J Oncol 19: 465-471, 2001.

21. Rumi MA, Sato H, Ishihara S, Ortega C, Kadowaki Y and Kinoshita Y: Growth inhibition of esophageal squamous carcinoma cells by peroxisome proliferator-activated receptorgamma ligands. J Lab Clin Med 140: 17-26, 2002.

22. Takahashi N, Okumura T, Motomura W, Fujimoto Y, Kawabata I and Kohgo Y: Activation of PPARgamma inhibits cell growth and induces apoptosis in human gastric cancer cells. FEBS Lett 455: 135-139, 1999.

23. Sato H, Ishihara S, Kawashima K, Moriyama N, Suetsugu H, Kazumori H, Okuyama T, Rumi MA, Fukuda R, Nagasue N and Kinoshita Y: Expression of peroxisome proliferator-activated receptor (PPAR) gamma in gastric cancer and inhibitory effects of PPARgamma agonists. Br J Cancer 83: 1394-1400, 2000.

24. Chang TH and Szabo E: Induction of differentiation and apoptosis by ligands of peroxisome proliferator-activated receptor gamma in non-small cell lung cancer. Cancer Res 60: 1129-1138, 2000 .
25. Tsubouchi Y, Sano H, Kawahito Y, Mukai S, Yamada R, Kohno M, Inoue K, Hla T and Kondo M: Inhibition of human lung cancer cell growth by the peroxisome proliferator-activated receptor-gamma agonists through induction of apoptosis. Biochem Biophys Res Commun 270: 400-405, 2000.

26. Nakashiro K, Begum NM, Uchida D, Kawamata H, Shintani S, Sato $M$ and Hamakawa H: Thiazolidinediones inhibit cell growth of human oral squamous cell carcinoma in vitro independent of peroxisome proliferator-activated receptor gamma. Oral Oncol 39: 855-861, 2003.

27. Begum NM, Nakashiro K, Kawamata H, Uchida D, Shintani S, Ikawa Y, Sato M and Hamakawa H: Expression of peroxisome proliferator-activated receptor gamma and the growth inhibitory effect of its synthetic ligands in human salivary gland cancer cell lines. Int J Oncol 20: 599-605, 2002.

28. Koga H, Harada M, Ohtsubo M, Shishido S, Kumemura H, Hanada S, Taniguchi E, Yamashita K, Kumashiro R, Ueno T and Sata M: Troglitazone induces p27Kip1-associated cell-cycle arrest through down-regulating Skp2 in human hepatoma cells. Hepatology 37: 1086-1096, 2003.

29. Hayashi N, Nakamori S, Hiraoka N, Tsujie M, Xundi X, Takano T, Amino N, Sakon M and Monden M: Antitumor effects of peroxisome proliferator activate receptor gamma ligands on anaplastic thyroid carcinoma. Int J Oncol 24: 89-95, 2004.

30. Fujimura S, Suzumiya J, Nakamura K and Ono J: Effects of troglitazone on the growth and differentiation of hematopoietic cell lines. Int J Oncol 13: 1263-1267, 1998.

31. Asou H, Verbeek W, Williamson E, Elstner E, Kubota T, Kamada N and Koeffler HP: Growth inhibition of myeloid leukemia cells by troglitazone, a ligand for peroxisome proliferator activated receptor gamma, and retinoids. Int J Oncol 15: 1027-1031, 1999.

32. Zang C, Liu H, Posch MG, Waechter M, Facklam M, Fenner MH, Ruthardt M, Possinger K, Koeffler HP and Elstner E: Peroxisome proliferator-activated receptor gamma ligands induce growth inhibition and apoptosis of human B lymphocytic leukemia. Leuk Res 28: 387-397, 2004.

33. Abe A, Kiriyama Y, Hirano M, Miura T, Kamiya H, Harashima $\mathrm{H}$ and Tokumitsu Y: Troglitazone suppresses cell growth of KU812 cells independently of PPAR $\gamma$. Eur J Pharmacol 436: 7-13, 2002.

34. Yin F, Wakino S, Liu Z, Kim S, Hsueh WA, Collins AR, van Herle AJ and Law RE: Troglitazone inhibits growth of MCF-7 breast carcinoma cells by targeting G1 cell cycle regulators. Biochem Biophys Res Commun 286: 916-922, 2001.

35. Wakino S, Kintscher U, Kim S, Yin F, Hsueh WA and Law RE: Peroxisome proliferator-activated receptor gamma ligands inhibit retinoblastoma phosphorylation and $\mathrm{G} 1 \rightarrow \mathrm{S}$ transition in vascular smooth muscle cells. J Biol Chem 2000 275: 22435-22441, 2000.

36. He G, Thuillier P and Fischer SM: Troglitazone inhibits cyclin D1 expression and cell cycling independently of PPAR $\gamma$ in normal mouse skin keratinocytes. J Invest Dermatol 123: 1110-1119, 2004.

37. Sugimura A, Kiriyama Y, Nochi H, Tsuchiya H, Tamoto K, Sakurada Y, Ui M and Tokumitsu Y: Troglitazone suppresses cell growth of myeloid leukemia cell lines by induction of p21WAF1/CIP1 cyclin-dependent kinase inhibitor. Biochem Biophys Res Commun 261: 833-837, 1999.

38. Lea MA, Sura M and Desbordes C: Inhibition of cell proliferation by potential peroxisome proliferator-activated receptor (PPAR) gamma agonists and antagonists. Anticancer Res 24: 2765-2771, 2004.

39. Welbourne T, Friday E, Fowler R, Turturro F and Nissim I: Troglitazone acts by PPAR $\gamma$ and PPAR $\gamma$-independent pathways on LLC-PK1-F+ acid-base metabolism. Am J Physiol Renal Physiol 286: F100-F110, 2004.

40. Palakurthi SS, Aktas H, Grubissich LM, Mortensen RM and Halperin JA: Anticancer effects of thiazolidinediones are independent of peroxisome proliferator-activated receptor gamma and mediated by inhibition of translation initiation. Cancer Res 61: 6213-6218, 2001.

41. Cobb JE, Blanchard SG, Boswell EG, Brown KK, Charifson PS, Cooper JP, Collins JL, Dezube M, Henke BR, Hull-Ryde EA, Lake DH, Lenhard JM, Oliver W Jr, Oplinger J, Pentti M, Parks DJ, Plunket KD and Tong WQ: N-(2-Benzoylphenyl)-Ltyrosine PPAR $\gamma$ agonists. 3. Structure-activity relationship and optimization of the N-aryl substitute. J Med Chem 41: 5055-5069, 1998. 